\title{
KEWAJIBAN INGKAR NOTARIS UNTUK MENJAGA KERAHASIAAN JABATAN DALAM PROSES PERADILAN
}

\author{
ANDINY RACHMADANI EKAPUTRI ${ }^{1}$ \\ Program Studi Magister Kenotariatan \\ Fakultas Hukum \\ Universitas Narotama Surabaya \\ Email : andiny_rachmadani@yahoo.com \\ RUSDIANTO SESUNG ${ }^{2}$ \\ Program Studi Magister Kenotariatan \\ Fakultas Hukum \\ Universitas Narotama Surabaya \\ Email: rusdianto@narotama.ac.id
}

\begin{abstract}
ABSTRAK
The obligation of notary in order to keep the deeds confidential is denial obligation for notary regulated in Notary Position Law article 16 section (1) F, explaining Notary should keep the deed content confidential and every information that obtained in process of making a deed except it listed on the Law. Caused to two basic questions that related to notary boundaries on giving information in order to keep the deed confidential on trial process and notary liability for loss suffered by the parties due to notary statements in court. Research result that notary have their rights to keep every information from client confidential based on Law and regulations, even some are not listed in the deed. According to notary right of denial, where they can deny their position as a witness, who can reveal all the secrets in some situations. Notary as Indonesian Citizen mustgive information on law process with Notary Honorary Council agreement, it regulated on article 66 section (1) Notary Position Law.
\end{abstract}

Keywords : Notary, Denial Obligation, Right Of Denial, Trust, Confidential Position.

\footnotetext{
${ }^{1}$ Mahasiswi Universitas Narotama Surabaya

${ }^{2}$ Dosen Universitas Narotama Surabaya
} 


\section{A. PENDAHULUAN}

Perkembangan hukum dan kebutuhan masyarakat tentang pengguna jasa notaris, telah terbentuk Undang-Undang Republik Indonesia Nomor 2 tahun 2014 Tentang Perubahan Atas Undang-Undang Nomor 30 Tahun 2004 Tentang Jabatan Notaris. Undang-Undang Jabatan Notaris ini diundangkan dengan maksud untuk menggantikan Reglement of Het Notaris Ambt inIndonesie (Stb.1860 No. 3, selanjutnya disebut PJPN-S. 1860 No. 3) tentangPeraturan Jabatan Notaris yang tidak sesuai lagi dengan perkembangan hukum dan kebutuhan masyarakat. Kedudukan seorang notaris sebagai suatu fungsionaris dalam masyarakat, hingga sekarang dirasakan masih disegani. Dengan berlakunya Undang-Undang Nomor 2 tahun 2014 Tentang Perubahan Atas UndangUndang Nomor 30 Tahun 2004 Tentang Jabatan Notaris, diharapkan dapat memberikan perlindungan hukum baik kepada masyarakat maupun terhadap notaris itu sendiri.

Notaris, adalah jabatan kepercayaan, sehingga seseorang bersedia mempercayakan sesuatu kepada notaris. Menurut hukum, akta yang dibuat oleh atau di hadapan notaris, adalah akta otentik, barang siapa yang membantah kebenaran suatu akta otentik, yang membantah harus dapat membuktikan sebaliknya. ${ }^{3}$

Dengan adanya suatu amanah yang diberikan kepada seorang notaris, tanggung jawab notaris terhadap suatu akta tidak hanya menyangkut kepentingan pribadi, tetapi juga menyangkut kepentingan umum. Sebagaimana diatur dalam kalimat terakhir Pasal 16 ayat (1) huruf f Undang-Undang Nomor 2 tahun 2014 Tentang Perubahan Atas Undang-Undang Nomor 30 Tahun 2004 Tentang Jabatan Notarisyakni :"kecuali Undang-Undang menentukan lain", dan kalimat terakhir seperti yang tercantum dalam Pasal 54 ayat (1) Undang-Undang Nomor 2 tahun 2014 Tentang Perubahan Atas Undang-Undang Nomor 30 Tahun 2004 Tentang Jabatan Notaris yakni : "kecuali ditentukan lain

olehperaturan perundang-undangan". Dalam kedua Pasal tersebut, terkesan seorangNotaris bisa memberitahukan isi akta kepada pihak yang tidak berkepentingan langsung kepada akta yang dibuatnya, asalkan didukung oleh peraturan perundang-undangan.

Akta Notaris adalah akta otentik yang memeliki kekuatan hukum dengan jaminan kepastian hukum sebagai alat bukti tulisan

\footnotetext{
${ }^{3}$ A. Kohar, Notaris Dalam Praktek Hukum, Bandung : Alumni, 1983, hlm. 28.
} 
yang sempurna (volledig bewijs), tidak memerlukan tambahan alat pembuktian lain, dan hakim terikatnya karenanya. Karena grosse akta Notaris sama kedudukannya dengan vonis keputusan hakim yang tetap dan pasti (inkracht van gewijsde) dan mempunyai kekuataan eksekutorial. Akta otentik merupakan suatu akta yang dibuat dalam bentuk yang ditentukan UndangUndang, oleh atau dihadapan pejabat umum yang berwenang untuk itu, ditempat dimana akta dibuatnya. $^{4}$

Selain membuat akta otentik, notaris juga berkewajiban secara langsung maupun tidak langsung untuk menjaga lancarnya proses hukum yang terjadi, termasuk di dalamnya berkenaan dengan proses peradilan, baik dalam peradilan pidana maupun perdata. Proses peradilan yang dimaksud di sini erat kaitannya dengan pembuktian, baik pembuktian dengan tulisan (bukti tertulis) maupun pembuktian dengan kesaksian (saksi).

Adapun yang dimaksud dengan akta otentik menurut Pasal 1868 KUHPerdata, yaitu suatu akta yang di dalam bentuk yang ditetapkan oleh Undang-Undang, dibuat

${ }^{4}$ Rusdianto Sesung, Kekuatan Pembuktian Akta Notaris yang Mengandung Kesalahan dalam Penulisan Komparisi, Jurnal. Al-Qanun, Vol. 20, No. 2, Desember 2017 oleh atau di hadapan pegawai umum yang berkuasa untuk itu, di tempat di mana akta dibuatnya. ${ }^{5}$

Sejak berlakunya Undang-Undang Nomor 30 Tahun 2004 tentang Jabatan Notaris yang kemudian diubah dengan Undang-Undang Nomor 2 Tahun 2014 tentang Jabatan Notaris, Pengadilan Negeri tidak berwenang untuk melakukan pengawasan terhadap notaris, pengawasan tersebut dilakukan oleh Menteri Hukum dan HAM sebagaimana ketentuan dalam Pasal 67 Undang-Undang Nomor 2 tahun 2014 Tentang Perubahan Atas Undang-Undang Nomor 30 Tahun 2004 Tentang Jabatan Notaris, yang menyatakan bahwa pengawasan atas notaris dilakukan oleh Menteri, kemudian di ayat berikutnya untuk melaksanakan pengawasan, Menteri membentuk suatu Majelis Pengawas yang berjumlah Sembilan (9) orang, yang terdiri atas unsur Pemerintah, Organisasi Notaris, dan Akademisi.

Bahwa panggilan yang dilakukan oleh penyidik, penuntut umum, atau hakim harus terlebih dahulu melalui mekanisme MKN Wilayah merupakan fase yang harus diikuti khususnya jika akan dilakukan pemeriksaan terhadap Notaris. Kewajiban untuk melalui

5 G.H.S. Lumban Tobing, Peraturan Jabatan Notaris, Jakarta : Erlangga, 1996, hlml. 55. 
mekanisme dari MKN Wilayah tersebut berlaku untuk penyidik, penuntut umum, atau hakim karena merupakan bagian dari hukum acara untuk panggilan terhadap Notaris, tetapi tidak berlaku bagi Notaris, sehingga jika ada Notaris yang secara ikhlas atau sukarela ingin langsung memenuhi panggilan dari penyidik, penuntut umum, atau hakim, maka hal tersebut diperbolehkan saja. Jika ada Notaris yang melakukannya, maka semuanya akan menjadi tanggung jawab dirinya sendiri dengan segala konsekuensi hukumnya. ${ }^{6}$

Dalam menindak lanjuti laporan masyarakat yang merasa dirugikan atas pembuatan akta, kemudian mengajukan laporan kepada Majelis Pengawas Daerah, kalau ada pelanggaran-pelanggaran yang terjadi maka telah diatur sanksi-sanksinya, berupa teguran lisan, tertulis, pemberhentian sementara ataupun permanen. Hal tersebut menunjukkan adanya kerahasiaan dan bahwa tidak dengan mudah untuk mengambil fotokopi Minuta Akta dan/atau surat-surat yang dilekatkan pada Minuta Akta atau Protokol Notaris dalam penyimpanan notaris dan memanggil notaris untuk hadir dalam pemeriksaan yang

\footnotetext{
${ }^{6}$ Adjie, Habib, and Muhammad Hafidh. "Memahami: Majelis Kehormatan Notaris (MKN)." Semarang: Sinergi Offset (2016).
}

berkaitan dengan akta yang dibuatnya atas Protokol Notaris yang berada dalam penyimpanan notaris.

\section{B. METODE PENELITIAN}

Penelitian ini merupakan penelitian normatif (normative legal research) yaitu penelitian yang dilakukan dengan cara mengkaji peraturan perundang-undangan yang berlaku atau ditetapkan terhadap suatu permasalahan tertentu. Penelitian ini menggunakan pendekatan Peraturan Perundang-undangan (statue approach), pendekatan penelitian melalui konsep, asas, doktrin, pendapat para sarjana (conceptual approach).

\section{PEMBAHASAN}

1. Batasan - batasan Notaris dalam memberikan keterangan agar tetap dapat menjaga kerahasiaan aktanya dalam proses peradilan

Merahasiakan isi akta dan keterangan baik lisan maupun tertulis yang diperoleh guna pembuatan akta, menjadikan hal tersebut sebagai rahasia jabatan Notaris. Kewajiban merahasiakan akta yang dibuat oleh Pejabat Notaris yang diperintahkan undang-undang (mandatory) tersebut, diperkuat dengan adanya sumpah/janji jabatan Notaris, dalam sumpah jabatan 
Notaris tersebut didalam nya disampaikan bahwaseorang Pejabat Notaris wajib untuk melaksanakan jabatan dengan amanah, jujur, saksama, mandiri dan tidak berpihak. Seorang Pejabat Notaris seharusnya mempunyai sifat atau dasar karakter seorang Pejabat umum yaitu:

1.1 Amanah: dapat dipercaya melaksanakan tugasnya yaitu melaksanakan perintah dari para pihak/orang yang menghendaki Notaris untuk menuangkan maksud dan keinginannya dalam suatu akta dan para pihak membubuhkan tanda tangannya pada akhir akta.

2.1 Jujur: tidak berbohong atau menutupnutupi segala sesuatunya.

3.1 Saksama: yaitu berhati-hati dan teliti dalam menyusun redaksi akta agar tidak merugikanpara pihak.

4.1 Mandiri: Notaris memutuskan sendiri akta yang dibuat itu berstruktur hukum yang tepat serta dapat memberikan penyuluhan hukum kepada klien.

5.1 Tak berpihak: netral, tidak memihak pada satu pihak.

6.1 Menjaga sikap, tingkah laku dan menjalankan kewajiban sesuai dengan kode etik Profesi, kehormatan, martabat dan tanggung jawab sebagai Notaris

7.1 Menjalankan kewajiban sesuai dengan kode etik Profesi, kehormatan, martabat dan tanggung jawab sebagai Notaris: menjaga kehormatan martabat Profesi Notaris, termasuk tidak menjelekkan sesama kolega Notaris atau perang tarif.

8.1 Akan merahasiakan isi akta dan keterangan yang diperoleh dalam pelaksanaan jabatan; Merahasiakan isi akta dan keterangan yang diperoleh, maksudnya Notaris harus mendengarakan keterangan dan keinginan klien sebelum menuangkannya dalam bentuk akta.

UUJN Pasal 16 ayat 1 huruf F UUJN No. 02 Tahun 2014 yang didalamnya menyatakan bahwa:

"Merahasiakan segala sesuatu mengenai akta yang dibuatnya dan segala keterangan yang diperoleh guna pembuatan akta sesuai dengan sumpah/janji jabatan, kecuali undang-undang menentukan lain." 7

\section{Tanggung gugat Notaris atas} Kerugian yang diderita oleh Para Pihak akibat Kesaksian Notaris di Pengadilan.

Pelaksanaan tugas Jabatan notaris yaitu dalam lingkup hukum pembuktian, hal ini karena tugas dan kewenangan notaris yaitu membuat alat bukti yang diinginkan

\footnotetext{
${ }^{7}$ Undang-Undang Jabatan Notaris No. 02 Tahun 2014 tentang Jabatan Notaris
} 
oleh para pihak dalam hal tindakan hukum tertentu. Keberadaan alat bukti tersebut dalam ruang lingkup atau tataran hukum perdata. Karena pekerjaan notaris membuat akta tersebut atas permintaan dari penghadap, tanpa adanya permintaan dari para penghadap, Notaris tidak akan membuat suatu apapun. notaris membuat akta berdasarkan alat bukti atau keterangan/ pernyataan para pihak yang dinyatakan atau diterangkan atau diperlihatkan kepada atau di hadapan notaris, dan selanjutnya notaris membingkainya secara lahiriah, formil dan materil dalam bentuk akta notaris, dengan tetap berpijak pada aturan hukum atau tata cara atau prosedur pembuatan akta dan aturan hukum yang berkaitan dengan tindakan hukum yang bersangkutan yang dituangkan dalam akta. Peran notaris dalam hal ini juga untuk memberikan nasehat hukum yang sesuai dengan permasalahan yang ada sebagaimana yang diwajibkan oleh pasal 15 ayat (2) huruf e. UUJN. Apapun nasehat hukum yang diberikan kepada para pihak dan kemudian dituangkan ke dalam akta yang bersangkutan tetap sebagai keinginan atau keterangan para pihak yang bersangkutan, tidak dan bukan sebagai keterangan atau pernyataan notaris. Dalam praktik notaris ditemukan kenyataan, jika ada akta notaris dipermasalahkan oleh para pihak atau pihak lainnya, maka sering pula notaris ditarik sebagai pihak yang turut serta melakukan atau membantu melakukan suatu tindak pidana, yaitu membuat atau memberikan keterangan palsu ke dalam akta notaris. Hal ini pun menimbulkan kerancuan, apakah mungkin notaris secara sengaja atau khilaf bersama-sama para penghadap/pihak untuk membuat akta yang diniatkan sejak awal untuk melakukan suatu tindak pidana. Dalam kaitan ini tidak berarti notaris terhindar dari perbuatan melawan hukum atau tidak dapat dihukum atau kebal terhadap hukum. Notaris bisa saja dihukum pidana jika dapat dibuktikan di pengadilan bahwa secara sengaja atau tidak disengaja notaris bersama-sama dengan para pihak/penghadap untuk membuat akta dengan maksud dan tujuan untuk menguntungkan pihak atau penghadap tertentu saja atau merugikan penghadap yang lain. Jika hal ini terbukti dalam persidangan, maka notaris tersebut wajib dihukum. Oleh karena itu, hanya Notaris yang tidak amanat dalam menjalankan tugas jabatannya, ketika membuat akta untuk kepentingan pihak tertentu dengan maksud untuk merugikan pihak tertentu atau untuk melakukan suatu tindakan yang melanggar 
hukum. $^{8}$

Dalam hal suatu akta notaris dibatalkan oleh putusan hakim di pengadilan, maka jika menimbulkan kerugian bagi para pihak yang berkepentingan, notaris dapat untuk memberikan ganti rugi, sepanjang hal tersebut terjadi disebabkan oleh karena kesalahan Notaris namun dalam hal pembatalan akta notaris oleh pengadilan tidak merugikan para pihak yang berkepentingan maka notaris tidak dapat dituntut untuk memberikan ganti rugi walaupun kehilangan nama baik. Seorang notaris baru dapat dikatakan bebas dari pertanggungjawaban hukum apabila akta otentik yang dibuatnya dan atau dibuat dihadapannya telah memenuhi syarat formil. Dan jika notaris tersebut terbukti melanggar ketentuan UndangUndang yang berlaku yaitu memenuhi unsur-unsur pidana yang terdapat dalam pasal pada KUHP maka notaris dapat dipidana atau dihukum.

8 Habib Adjie, Hukum Notaris Indonesia (tafsir tematik terhadap UU No 30 tahun 2004 tentang jabatan notaris),Bandung,Refika Aditama, 2008, hal.24.

\section{KESIMPULAN DAN SARAN}

KESIMPULAN

1. Berdasarkan analisis mengenai batasbatas kerahasiaan akta Notaris dalam Proses dikaitkan dengan adanya hak ingkar Notaris, terdapat batasan untuk menjaga kerahasiaan. Kewajiban Notaris mutlak untuk menjaga kerahasiaan dalam akta yang dibuatnya dan beserta dengan informasi yang menyertainya. Hal ini tertuang dalam aturan yang menyertai dan mengaturnya yaituPasal 1909 ayat 3 KUH Perdata.

2. Tanggung gugat Notaris akibat Kesaksian Notaris di Pengadilan jika terjadi perkara pidana harus dibuktikan berdasarkan putusan hakim di pengadilan. Apabila akta tersebut menimbulkan perkara bagi para pihak yang berkepentingan, notaris dapat dituntut untuk dipidana hal tersebut terjadi disebabkan oleh karena kesalahan Notaris. namun dalam hal pembatalan akta notaris oleh pengadilan tidak merugikan para pihak yang berkepentingan maka notaris tidak dapat dituntut, walaupun kehilangan nama baik. Seorang notaris baru dapat dikatakan bebas dari pertanggungjawaban hukum apabila akta otentik yang dibuatnya dan atau dibuat 


\section{DAFTAR PUSTAKA} formil.

\section{SARAN}

Disarankan untuk Majelis Kehormatan Notaris, agar dapat menjamin adanya pendampingan hukum bagi Notaris melalui lembaga Majelis Kehormatan Notaris apabila nanti Notaris tersebut diduga telah melakukan pelanggaran atau malpraktek dalam proses pembuatan akta otentik atau saat menjalani proses oleh pihak yang berwenang, serta disarankan pula meskipun undang-undang memberikan perlindungan hukum kepada Notaris dalam hal pemeriksaan perkara khususnya perkara pidana, hendaknya notaris tetap menjaga kekuatan pembuktian akta otentik yang dibuatnya dengan memperhatikan aspek lahiriah, aspek formal dan aspek materiil, sehingga aktanya mempunyai kekuatan hukum yang sempurna, dengan demikian Notaris terhindar dari perbuatan pidana.

\section{Buku-Buku}

Habib Adjie, Hukum Notaris Indonesia (tafsir tematik terhadap UU No 30 tahun 2004 tentang jabatan notaris), Bandung,Refika Aditama, 2008.

A.Kohar, Notaris Dalam Praktek Hukum, Bandung : Alumni, 1983.

G.H.S. Lumban Tobing, Peraturan Jabatan Notaris, Jakarta : Erlangga, 1996, Rusdianto Sesung, Kekuatan Pembuktian Akta Notaris yang Mengandung Kesalahan dalam Penulisan Komparisi, Jurnal. Al-Qanun, Vol. 20, No. 2, Desember 2017

Adjie, Habib, and Muhammad Hafidh.

"Memahami: Majelis Kehormatan Notaris(MKN)." Semarang: Sinergi Offset (2016). 